\title{
Deleuze's Bergsonism: Multiplicity, Intuition, and the Virtual
}

\section{Raniel SM. Reyes}

\begin{abstract}
This paper aims to explicate Gilles Deleuze's philosophy of Bergsonism. Specifically, I expound on Deleuze's reconstruction of Bergson's concepts of intuition, the virtual, and duration. Bergson's formulation of these concepts is critically informed by traditional science and metaphysics' insular obsession with quantitative differences, succession, homogeneity etc. In the eyes of Deleuze, this preoccupation redounds to the failure in perceiving real differencesthe realm of qualitative difference, duration, intuition etc. Accordingly, real difference and the creative differentiation of its corollary concepts form part of Deleuze's Transcendental or Virtual Empiricism. Ultimately, tracing Deleuze's intellectual indebtedness to Bergson's differential philosophy does not only disclose his own way of overcoming or antagonizing traditional science and metaphysics, but more importantly, it opens us to a life of self-reflexivity, pure becoming, and infinite durations.
\end{abstract}

Keywords: Deleuze, intuition, virtual, transcendental empiricism

\section{Introduction}

$\mathrm{D}$

eleuze's intellectual project is first and foremost a philosophy of immanence. This philosophy according to Jeffrey Bell is "an attempt to understand the emergence of identities, whether social, political, individual, ontological etc. in a manner that does not entail a condition that transcends the conditioned." 1 What can be derived from this definition is that all configurations of knowledge and experiences or as what Bell terms as 'identities' are overtly or implicitly conditioned by the material configurations of life. In other words, all concepts that can be gleaned from

${ }^{1}$ Cf. Jeffrey Bell, "Between Individualism and Socialism: Deleuze's Micropolitics of Desire," in Jeffrey Bell's Selected Writings - Southern Louisiana University Faculty Links (17 October 2003), <https://www2.southeastern.edu/Academics/Faculty/jbell/micropolitics.pdf $>$, p. 2.

(c) 2016 Raniel SM. Reyes

http://www.kritike.org/journal/issue_19/reyes_december2016.pdf

ISSN 1908-7330

$(c c)$ BY-NC-ND 
the philosophy of immanence such as difference, becoming, and history are all related to and are dynamic conduits of life. It is likewise observable in the whole the Deleuzian literary oeuvre how Deleuze critically elucidates, engages, and contrasts these concepts (forming part of his philosophy of immanence) with the philosophy of transcendence.

Deleuze is among the contemporary French philosophers who attempts to liberate philosophical thinking from its subjection to 'transcendence.' He grapples with this concept by contrasting it with 'immanence.' In advancing this complex task, he goes back to previous maverick philosophers, such as, David Hume, Henri Bergson, Baruch Spinoza, and Friedrich Nietzsche. However, instead of simply being the mouthpiece of these thinkers' theories of immanence, Deleuze engages in a "mutual exchange" with these philosophers, as François Zourabichvili describes. ${ }^{2}$ In other words, in Deleuze's unabridged engagement with these scholars, there is a process of borrowing and giving-a friendship and dissension altogether.

Deleuze uses the term "immanence" interchangeably with "empiricism" - although he himself only admits his empiricist stance in the English Language Edition of Dialogues with Claire Parnet. ${ }^{3}$ In relation to this, Vincent Descombes, in his book Modern French Philosophy, describes the project of Deleuze as a search for a transcendental empiricism. ${ }^{4}$ French poststructuralist thinkers like Jacques Derrida, join Deleuze in his quest for a new foundation that contrasts the transcendental field characterized by immanent dynamics and rhizomic dislocations. ${ }^{5}$ For Constantine Boundas, Deleuze's philosophy is the war-machine par excellence. ${ }^{6}$ This radical machinery consists of a philosophical assemblage of Hume, Bergson, Spinoza and Nietzsche who share "a secret bond formed by the critique of the negative, the culture of joy, the hatred of interiority, the externality of forces and relations, and the denunciation of power."7 Deleuze's immanent philosophy criticizes transcendental idealism and phenomenology. For

${ }^{2}$ François Zourabichvili, Deleuze: A Philosophy of the Event (Edinburgh: Edinburgh University Press, 2012).

${ }^{3}$ Gilles Deleuze and Claire Parnet, Dialogues, trans. by Hugh Tomlinson and Barbara Habberjam (London: Athlone Press, 1987).

${ }^{4}$ Gilles Deleuze, Empiricism and Subjectivity: An Essay on Hume's Theory of Human Nature, trans. by Constantin Boundas (New York: Columbia University Press, 1990), 3.

${ }^{5}$ Empiricism is characterized by Derrida "as a pure thought of pure difference." Jacques Derrida, Writing and Difference, trans. by Alan Bass (Chicago: University of Chicago Press, 1978), 151.

6 Constantin Boundas, Translator's Introduction to Deleuze, Empiricism and Subjectivity, 4 .

${ }^{7}$ Gilles Deleuze, "Lettre à Michel Cressole," in Michel Cressole, Deleuze (Paris: Editions Universitares, 1973), 110. Cf. Gilles Deleuze, "Letter to a Harsh Critique," in Negotiations, trans. by Martin Joughin (New York: Columbia University Press, 1995), 3-12.

(c) 2016 Raniel SM. Reyes

http://www.kritike.org/journal/issue 19/reyes december2016.pdf

ISSN 1908-7330

(cc) BY-NC-ND 
example, his critical diagnosis of Husserlian phenomenology is due to its fixation with the evidence provided by pure consciousness. Deleuze undermines phenomenology in pursuit of an ontology of nomadically intensive forces and protean folds.

\section{Bergsonism and the Theory of Multiplicity}

Aside from the different articles published by Deleuze about Bergson's philosophy, Deleuze published his book on Bergson entitled, Bergsonism in 1966. ${ }^{8}$ In this book, Deleuze invites a return to Bergson through a reconstruction and problematization of the latter's important concepts, such as, the philosophical method of intuition and the concepts of duration and the virtual. "Bergsonism" is used by Deleuze not only as a philosophical device to emancipate Bergson's philosophy from its dogmatic or bigoted appropriation (limited to vitalism or irrationalism), but rather, it is presented as a creative effort to revitalize the question of life itself-in contrast to Heideggerian Being, Kantian noumenon, as well as a response to fixed and purely quantitative scientific theories.

Generally, Bergsonism offers a radical counter-history of philosophy. It is a philosophizing against what Deleuze calls as State philosophy or the French-style history of philosophy that is predominantly inhabited by 'bureaucrats of pure reason who speak in the despot's shadow and are in complicity with the State. ${ }^{\prime 9}$ In Dialogues, Deleuze claims that there is something in Bergson that escapes the coalescing net of State philosophy. ${ }^{10}$ Deleuze further explains:

My way of getting out of it at that time, was I really think, to conceive of the history of philosophy as a kind of buggery or, what comes to the same thing, immaculate conception. I imagined myself getting onto the back of an author, and giving him a child, which

\footnotetext{
${ }^{8}$ Gilles Deleuze, Bergsonism, trans. by Hugh Tomlinson and Barbara Habberjam (New York: Zone Books, 1988). Albeit as early as Empiricism and Subjectivity, Deleuze already identifies his interest in the Bergsonian philosophy. Aside from these two books, Bergsonism is also influential in Difference and Repetition where he articulates the concepts of difference, memory, and repetition, as well as in the twin literatures, Cinema 1: The Movement-Image and Cinema 2: The Time-Image, where the terms such as duration, memory, and movement are discussed. In addition, it is in Deleuze's writings on cinema which signals his 'anti-Bergsonian Bergsonian' stance, in the same vein that the critical theorist Theodor Adorno is an 'anti-Hegelian Hegelian.'

${ }_{9}^{9}$ Brian Massumi, Translator's Foreword ("Pleasures of Philosophy") to Gilles Deleuze and Felix Guattari, A Thousand Plateaus: Capitalism and Schizophrenia (Minneapolis: University of Minnesotta Press, 1987), ix. Gilles Deleuze, "Nomad Thought," in The New Nietzsche, ed. by Donald Allison (Cambridge: MIT Press, 1985), 148.

${ }^{10}$ Deleuze and Parnet, Dialogues, 15.
} 
would be his and which would at the same time be a monster. It is very important that it should be his child, because the author had to say everything that I made him say. But it also had to be a monster because it was necessary to go through all kinds of de-centerings, slips, break ins, secret emissions, which I really enjoyed. My book on Bergson seems to me a classic case of this. ${ }^{11}$

Specifically, the primary goal of Bergsonian philosophy is to overcome the metaphysics of transcendence, invoking a novel kind of philosophy of immanence or virtual or transcendental empiricism. In "Introduction to Metaphysics," Bergson defines this novel kind of empiricism as "one which purposes to keep as close to the original as possible, to probe more deeply into its life, and by a kind of spiritual auscultation, to feel its soul palpitate; and this true empiricism is the real metaphysics. ${ }^{12}$ Bergsonism is similar to the Hegelian project of overcoming Cartesian metaphysics. Likewise, Hegelian philosophy argues that the nature of reality can already be accessed thinly through a series of dialectical struggles, unlike the Kantian demarcation of the phenomenal and noumenal world. ${ }^{13}$ But instead of an outright extermination of the distinction between the phenomenal and the noumenal world, and radicalization of the privileging of the ideal over the material, Bergson reorients the fundamental pillars of metaphysics. In Matter and Memory, for example, we can see how he advocates a creative undermining of the traditional dualisms between body/matter and the mind/spirit, to name a few. Via a brief excursus to Hume's theory of immanence, we may be able to understand this Bergsonian position better.

According to Hume's theory of immanence, traditional philosophy's extensive adherence to dualism can be surmounted by searching the inbetween of binaries that will turn the set into a multiplicity that is irreducible to the number of its parts. ${ }^{14}$ In Dialogues, Deleuze and Parnet characterize Hume's empiricist philosophy as a practical philosophy of "becoming-

\footnotetext{
${ }^{11}$ Deleuze, "Lettre à Michel Cressole," 111. Cf. footnote no. 7.

${ }^{12}$ Henri Bergson, "Introduction to Metaphysics," in Creative Mind, trans. by Mabelle Andison (New Jersey: Littlefield, Adams \& Co., 1965), 175.

${ }^{13}$ A significant import derivable from the Hegelian philosophy is that Kant's noumenon can already be known (indirectly) in the arena of historical configurations. When things are viewed in the ambit of the immanence, all epistemological binaries and ideas can be mediated. Thus, the nature of reality is fathomable through a series of struggles because in the first place, nature and reality are rational. See G.W.F. Hegel, Science of Logic, trans. by A. V. Miller (London: Allen \& Unwin; New York: Humanities Press, 1969), 31. See also G.W.F. Hegel, "Encyclopeedia Logic: Preliminary Conception," in The Hegel Reader, ed. by Stephen (Malden, MA: Blackwell Publishing, 1998), 140.

${ }^{14}$ Deleuze and Parnet, Dialogues, 132.
}

(c) 2016 Raniel SM. Reyes

http://www.kritike.org/journal/issue 19/reyes december2016.pdf

ISSN 1908-7330

(c) BY-NC-ND 
multiple, instead of being-one, a being-whole or being as subject." 15 Hence, concepts and impressions are not deemed as individuated givens or as eitheror identities. Rather, they are seen as multiplicities found in between identifiable terms. Deleuze calls this as the AND between identities-a thinking with AND and not with IS. ${ }^{16}$ In other words, this thinking is about the machinic dynamisms between identities pertaining to life itself and not thinking about life or about the IS of life, since thinking about life individuates it from thinking. In short, thinking with a Deleuzian AND is yet another thinking with IS. Thinking of this sort, however, includes paratactic conjunctions and principles. This brand of double-thinking for Deleuze is an empiricism that seeks to determine and think the real conditions under which something wholly new is produced, and not simply a repetition of the same. ${ }^{17}$ Therefore, the Humean formulation of difference and repetition is Deleuze's alternative to the logic of dialectics, which is a subsidiary of transcendental philosophy. Writ large, the differential philosophy that can be unearthed from Hume's materialist philosophy contains the affirmative power to escape the totalizing hand of dialectical sublation or transcendental thinking.

The Bergsonian version of overcoming traditional metaphysics manifestly runs parallel to the aforementioned Humean project. It does not aspire for the abolition of the distinction between different conceptual binaries, rather, it aims for the reformulation of the mind-body or idealmaterial world problem in a manner that the two binaries achieve a creative interpenetration or differentiation. In Bergson's view, even though Kant's Copernican Revolution has undoubtedly contributed to the architecture and course of contemporary philosophizing, it remains unsuccessful in liberating thought from the yoke of transcendentalism. He opines that as long as traditional philosophy (or science and metaphysics anchored on a unitarian or identitarian principle) lives under the delusion of entirely appropriating the real by critical analysis and logical deduction, and locates the conditions of experience outside experience, it will always suffer a miscarriage. ${ }^{18}$ To borrow Bergson's words in Introduction to Metaphysics, "metaphysics has nothing in common with the generalization of experience, and nevertheless it

\footnotetext{
15 Ibid.

${ }^{16}$ Ibid., 57.

17 Jeffrey Bell, Deleuze's Hume: Philosophy, Culture, and the Scottish Enlightenment (Edinburgh: Edinburgh University Press, 2009), 3. This is likewise present in Nietzsche's concept of the Eternal Return. In Difference and Repetition, Deleuze reformulates the Nietzschean conceptualization of the Eternal Return not as the recurrence of the Same, but of the differentthe ritornello of becoming. See Gilles Deleuze, Difference and Repetition, trans. by Paul Patton (New York: Columbia University Press, 1994), 41.

18 Cf. Valentine Moulard-Leonard, Bergson-Deleuze Encounters: Transcendental Experience and the Thought of the Virtual (New York: State University of New York Press, 2008), 91.
} 
could be defined as integral experience." 19 Thus, Bergson's critical diagnosis of Kantian metaphysics in particular and traditional philosophy in general, is informed by the affirmative goal of transvaluating transcendental philosophy.

Further, Deleuze expounds in Bergsonism that when we philosophize from the vantage point of traditional dualism or thinking in terms of gradation (degree): "Conceiving everything in terms of more or less, seeing nothing but difference in degree or differences in intensity ... is perhaps the most general error of thought, the error common to science and metaphysics." 20 Deleuze's aforesaid argument is two-fold: firstly, it accentuates a philosophical blunder or 'false problem' authored by transcendental philosophy in privileging a metaphysical thinking in terms of difference in degree (which presupposes the two theories of tendencies, namely, difference in degree and difference in kind); and, secondly, it introduces the two kinds of multiplicity. ${ }^{21}$ Regarding the first point, this error of thought Deleuze refers to as the crime of traditional western scholarship (science and metaphysics) because it differentiates knowledge, concepts, and relations in terms of quantitative configurations. ${ }^{22}$ In the book, BergsonDeleuze Encounters: Transcendental Experience and the Thought of the Virtual, Valentine Moulard-Leonard comprehensively contends that traditional philosophy is enslaved by the intellect's "pragmatic orientation and its resulting tendency to analyze ... to reify and hypostasize its own mental

${ }^{19}$ Bergson, “Introduction to Metaphysics," 200.

${ }^{20}$ Cf. Deleuze, Bergsonism, 20.

${ }^{21}$ In Deleuze's small collection of essays, Essays Critical and Clinical, there is a short essay entitled, "He Stuttered!" where he claims that language itself can stutter. See Gilles Deleuze, Essays Critical and Clinical, trans. by D.W. Smith and M. A. Greco (Minneapolis: University of Minnesota Press, 1997), 108. Of course, this goes against the grain of traditional thinking or philosophy, which is anthropological. In other words, it runs counter to the dominant narrative that it is only the speaking human beings who can stutter. In Difference and Repetition, Deleuze likewise criticizes the mediocre mantra of traditional theorizing that 'everybody knows.' This aforementioned belief is grounded on the 'Old Image of Thought' that has haunted the philosophies of Plato, Kant, Descartes, to name a few. However, history is witness to the inability of all kinds of philosophical theorizations modeled after this transcendental image of thought to fashion entirely new events and concepts. See Deleuze, Difference and Repetition, 134. In short, for Deleuze, language grounded on the old image of thought must be deterritorialized (in style, content, and intensity) to the point that its limits are to be obliterated towards the state of stuttering - an unfamiliar territory and a plane of pure becoming and pragmatics.

${ }^{22}$ In relation to this, Bergson opines that, "Metaphysics dates from the day when Zeno of Elea pointed out the inherent contradiction of movement and change, as our intellect represents them." See Bergson, Creative Mind, 17. This entails that even before Plato defined reality or truth as that which is immutable, the pre-Socratic thinker Zeno already considered movement and change as absurd.

(c) 2016 Raniel SM. Reyes

http://www.kritike.org/journal/issue 19/reyes december2016.pdf

ISSN 1908-7330

(c) $\mathrm{BY}-\mathrm{NC}-\mathrm{ND}$ 
states ... things and concepts." ${ }^{23}$ In relation to Kantian metaphysics, MoulardLeonard further claims:

According to Bergson ... transcendental philosophers, who beyond experience seek the conditions for experience have simply defined the truth or falsity of a problem by the possibility or impossibility of its receiving a solution .... In accordance with this view, the conditioned (experience) would have to precede and condition its very conditions (the forms of time and space). This means that by defining the transcendental in terms of 'condition of experience,' Kant could not escape the psychological illusions that his critique sought to dispel. ${ }^{24}$

Metaphysics of this sort discards any type of creative production and a future philosophy. Bergson repudiates transcendental metaphysics and asserts that our mind is capacitated to intuitively re-orient itself to produce protean and machinic constellations of concepts that are from the conservative logic of the One and the Multiple. In Bergson's language, "To philosophize means to reverse the habitual direction of the workings of thought." 25

With the dominance of science and metaphysics, a unitarian/absolute idea of the One is conceived and is combined with its opposite, the Multiple, "to reconstruct all things from the standpoint of the forced opposed to the multiple or to the deterioration of the One." ${ }^{26}$ In order to overcome this problem, Bergson formulates the concept of multiplicity, which Deleuze describes as Bergson's greatest invention. In Time and Free Will, multiplicity is no longer used as a mere description of things, since it transforms into an independent or substantive term. ${ }^{27}$ This metamorphosis allows us to operate on a radically new plane of philosophizing or image of thought. Gone are the days where philosophical questions revolve around the problem, "Is it one or multiple?" According to Bergson, the problem posed by traditional scholarship is not already a question of the One-Multiple opposition, but rather on the type of multiplicity, i.e., whether it is quantitative or qualitative?

\footnotetext{
${ }^{23}$ Moulard-Leonard, Bergson-Deleuze Encounters, 96.

24 Ibid., 97.

${ }^{25}$ Bergson, "Introduction to Metaphysics," 191; Cf. Moulard-Leonard, Bergson-Deleuze Encounters, 96.

${ }^{26}$ Deleuze, Bergsonism, 47.

${ }^{27}$ Cf. Bergson, "Introduction to Metaphysics," 176; Cf. Moulard-Leonard, BergsonDeleuze Encounters, 142.
}

(C) 2016 Raniel SM. Reyes http://www.kritike.org/journal/issue 19/reyes december2016.pdf ISSN 1908-7330 
The new characterization of multiplicity is inspired by the physicianmathematician G.B.R. Riemann. He creates a typology of multiplicities that can provide a distinction between space and duration, matter and memory, objectivity and subjectivity, as well as the possible and the virtual. ${ }^{28}$ The two kinds of multiplicities are 'quantitative multiplicities' and 'qualitative multiplicities.' The former is constitutive of the principle of its own metrics by which the measure of one of its parts being given by the number of elements it contains. ${ }^{29}$ It belongs to the realm of science and metaphysics (or space). On the other hand, the latter belongs to the sphere of duration.

The intellectual tendencies of difference in degree and kind, parallel to the multiplicities of space and duration. In Bergson's eyes, all other divisions and dualities are derived from the aforementioned multiplicities..$^{30}$ In his view:

The first implies going all around it, the second entering into it. The first depends on the viewpoint chosen and the symbols employed, while the second is taken from no viewpoint and rests on no symbol. Of the first kind of knowledge [analysis] we shall say that it stops at the relative; of the second [intuition] that, wherever possible, it attains the absolute. ${ }^{31}$

Bergson claims that the multiplicity of space is a kind of subjective perception that empowers us to see all calculable, categorizable, and indifferent quantitative changes. ${ }^{32}$ Space, as a kind of multiplicity and perception, is merely a home to difference in degree because of its attribute of quantitative homogeneity. Things' variations with all other things are true in space but only in the ambit of difference in degree. At this juncture, it can be claimed that difference in kind does not exist between duration and space, since it can only be found in the plane of duration where qualitative difference exists. Conversely, the multiplicity of duration is an objective kind of perception which can bear all the expressions and aspects of difference in kind through its aptitude of qualitative self-variation. Deleuze describes duration as the invisible, non-measurable, and more importantly, "that which

${ }^{28}$ Bergson inverts the way we might normally think this distinction, with the 'subjective' denoting anything that is held to be completely and adequately known and the 'objective' being applied to what is known in a way that recognizes new impressions could be substituted and added to our idea of a thing. Cf. Deleuze, Bergsonism, 47.

${ }^{29} \mathrm{Ibid}$.

${ }^{30}$ Ibid., 31.

${ }^{31}$ Bergson, "Introduction to Metaphysics," 159; Cf. Moulard-Leonard, Bergson-Deleuze Encounters, 91-92.

${ }^{32}$ Moulard-Leonard, Bergson-Deleuze Encounters, 92.

(c) 2016 Raniel SM. Reyes

http://www.kritike.org/journal/issue 19/reyes december2016.pdf

ISSN 1908-7330

(cc) BY-NC-ND 
divided only by changing in kind, that which was susceptible to measurement only by varying its metrical principles at each stage of the division." 33 Thus, it is in the plane of duration where things vary in kind from all the rest, and from itself. It is here that we experience an affirmative differentiation of our respective states or conditions. Moreover, the multiplicity of duration refers to a pure interiority with perpetual succession; while space is pure exteriority devoid of succession. Whereas the role of space is to provide exteriorized, homogenous, and discontinuous frames, the function of duration is to render interiorized, heterogeneous, and continuous successions. For Deleuze, a dialectical relationship must be established between auxiliary space and homogenous time. He accentuates that the project of philosophizing from the standpoint of duration rather than of space is the heart of Bergsonism. It is because the direction of duration is constitutive of purity, in the sense that this kind of philosophizing can disclose real difference - the perennial task of philosophy. ${ }^{34}$

\section{The Philosophy of Intuition and the Virtual}

A profound understanding of duration can only be done justice via the philosophical method of intuition. Although the description "philosopher of difference" is usually associated with Nietzsche, Derrida, and Lyotard, to name a few, Bergson's philosophy of intuition is, for Deleuze, the most convincing response to traditional science and metaphysics. The intellectual tendency of difference located in duration can only be produced and activated through Bergson's notion of integral experience or intuition.

Primarily, intuition presupposes duration. It is a movement that spawns the emergence of our own respective durations, where different durations interact; durations that are "both inferior and superior to us, though nevertheless, in a certain sense, interior to us." ${ }^{35}$ Intuition evokes us to de-center our myopic subjective durations that thereby opens us to the durations of other entities (be it humans or other world entities) and temporalities. In other words, intuition is a principle of alterity that educates us about our contingent and partial involvement in the sea of differences. ${ }^{36}$ Of course, this aforesaid view parallels with Hume and Nietzsche's definitions of subjectivity. For Hume, the self is merely an assemblage of impressions or memories; and calling the self as such is just a matter of habitual practice. For Nietzsche, subjectivity is understood as the body being

\footnotetext{
${ }^{33} \mathrm{Ibid} ., 40$.

${ }^{34}$ Cf. Henri Bergson, Matter and Memory, trans. by N. M. Paul and W. S. Palmer (New York: Zone Books, 2002), 71; Cf. Deleuze, Bergsonism, 17-35.

${ }^{35}$ Bergson, Creative Mind, 217; Cf. Deleuze, Bergsonism, 33.

${ }^{36}$ Cf. Bergson, Matter and Memory, 193, 204; Cf. Deleuze, Bergsonism, 75.
}

(C) 2016 Raniel SM. Reyes 
the conduit of the different life-forces (active and reactive); and the manner on how we capitalize these forces determine whether we exhibit the ascending or descending life-typology. ${ }^{37}$

It is in What is Philosophy? where Deleuze (along with Guattari) characterizes intuition as a line of thinking or as one of the elements of a plane of immanence; he refers to intuition as a philosophical method derived from Bergson's philosophy. ${ }^{38}$ According to Deleuze, "Intuition is neither a feeling, an inspiration, nor a disorderly sympathy, but a fully developed method ... in philosophy." 39 Contrary to the common assumption, intuition is not categorically contradictory to science. In fact, Deleuze explains that in the Bergsonian context, this principle is a rigorous and precise discipline bearing the capacity to be prolonged and transmitted like science. ${ }^{40}$ However, unlike science and metaphysics, intuition does not perceive binaries in terms of binary opposition, like between being and non-being, and order and disorder. It does not succumb to conventional science and metaphysics' adherence to the principle of negation, which is a 'false problem' in Deleuze's view, like the problem involving Kantian metaphysics. This is the reason why Deleuze proposes for the re-activation of the differences in kind. Intuition can exhume this self-critical tendency within the difference in degree and can engender the intellect to turn against itself towards the articulation of the real. ${ }^{41}$

Deleuze thinks that since experience only affords us composites, intuition must divide them in terms of quantitative and qualitative propensities "according to the way in which it combines duration and extensity as they are defined as movements, directions of movements." ${ }^{42} \mathrm{He}$

${ }^{37}$ The Will to Power is the genealogical element of forces that configures and delimits variations of forces and relation of bodies. It serves as a genealogical determining principle for the relation of forces and bodies. This activity only becomes possible since the will to power is immanent to the relation of forces it defines and delimits. Cf. Gilles Deleuze, Nietzsche and Philosophy, trans. by Hugh Tomlinson (London: Athlone Press, 1983), 50. A corollary principle of the will to power is the concept of the Eternal Return. Nietzsche devises this principle to test what kind of life do we want to recur-whether an ascending or descending life in a world of divine accidents. In a nutshell, the will to power is the synthesis and determining principle both of the differential element of forces, and the eternal return (the affirmation of difference and chance).

${ }^{38}$ Adrian Parr, ed., The Deleuze Dictionary (Edinburgh: Edinburgh University Press, 2005), 135.

${ }^{39}$ Deleuze, Bergsonism, 13.

${ }^{40}$ Ibid., 14. Interestingly, it appears that Deleuze gives more trust to the precision and general applicability of the philosophical method of intuition than Bergson. For Bergson, in utilizing intuition as an instrument of communication, symbols or metaphors must be used to comprehend what goes beyond the frontiers of traditional perception and language.

${ }^{41}$ Cf. Ibid., 11.

42 Ibid., 22. The ontology of Reality or the Absolute is constitutive of two composites or intellectual tendencies-difference in degree (space) and difference in kind (duration). Science, for instance, can claim that in revealing to us the difference in degree or quantitative

(c) 2016 Raniel SM. Reyes

http://www.kritike.org/journal/issue 19/reyes december2016.pdf

ISSN 1908-7330

$(c c))$ BY-NC-ND 
further asserts that scientific and metaphysical thinking are incapacitated in perceiving differences in kind. In the case of metaphysics, it only sees quantitative difference between a spatialized time and an eternity that it presupposes to be primary. ${ }^{43}$ Whereas in the case of science, there is no definition of mechanism beyond spatialized time, according to which beings no longer present anything but difference of position, dimension, and proportion. ${ }^{44}$ Because science and metaphysics only enable us to perceive things according to difference in degree, we are prevented from transcending our experiences. Kantian metaphysics seamlessly epitomizes this failure for it has attempted to convey the possibility of the existence of noumenal realities, despite denying the possibility of experiencing them as such.

In attempting to make sense of the condition of experience, Bergson turns into a philosopher of immanence a la Spinoza, Hume, or Nietzsche, in utilizing the body as a subjectivity and creative fiction-a process of going beyond experience in order to reveal the condition of experience. In Bergsonism, the body is regarded as a protean site for affectivity and memory. Because of memory, the body transfigures into a 'duration in time,' and not simply a pure instantaneity and succession. In other words, representation from a general viewpoint is composite of two directions that differ in pure presences and elusive from any kind of representation. These two directions that Deleuze talks about are perception and memory (recollection). Although each direction surmounts the borders of scientific and metaphysical representations, they interpenetrate each other and constantly involve "exchanging something of their substance as by process of endosmosis." 45 Intuition allows us to transcend our experiences which are the by-products of the incessant interweaving of perception and memory. Rising above our experiences involves a movement characterized by broadening, tightening, and narrowing that leads to the conditions of experience-the focal point of differences in kind. Consequently, intuition enables us to push further into the boundaries of experience-to the state of pure perception (matter/nature) and memory (past). ${ }^{46}$ This becomes possible because of memory.

homogeneity between things is able to depict us the real. The undeniable advancement in modern physics attests to this claim. It provides us with more accurate analysis and calculations of things using the best of technologies that pose critical challenge to the contemporary human condition. As a response, Deleuze argues that this is merely a delusion, "to the extent that we project the real landscape of the first slope onto the other. If the illusion can be repressed it is because of ... of duration, which gives differences in kind corresponding in the final instance to difference of proportion as they appear in space, and already in matter and extension." Ibid., 35.

${ }^{43}$ Cf. Ibid., 23.

${ }^{44}$ Cf. Ibid.

${ }^{45}$ Cf. Deleuze, Bergsonism, 26.

${ }^{46}$ Ibid., 27. 
The philosophy of intuition links duration to memory in terms of the conservation and preservation of the past in the present. For Deleuze, they are not only linked, but are coextensive with each other. ${ }^{47}$ As a caveat, both multiplicities are not aperiodic or intermittent series of moments that repeat identically because they are characterized by continuous heterogeneity: "On the one hand, the following moment always contains, over and above the preceding one, the memory the latter has left it; on the other hand, the two moments contract or condense into each other since one has not yet disappeared when another appears." ${ }^{48}$ Accordingly, the 'present' which endures divides at each instant traverses two directions. Deleuze terms these directions as the two kinds or movements of memory: recollection-memory and contraction-memory. Whereas the former is a movement that is oriented and expanded toward the past, the latter is contracted, and contracting towards the future. ${ }^{49}$

Going beyond the human condition likewise opens us to the horizon of the nonhuman. This inspires Bergson to develop a differential philosophy which capacitates thought to transcend the human condition. In Deleuze's opinion, Bergson fashions the possibility for the investigation of the nonhuman by questioning the privilege of natural perception and the subordination of movement to poses. ${ }^{50}$ This new world is an estuary where images move and collide in a state of universal variation and undulation. ${ }^{51}$ To make it more Deleuzian, this is a realm of pure rhizomic becomings and virtualities - devoid of any constancy, center, axis, and gradations. ${ }^{52}$ On the one hand, this event revolutionizes conventional philosophizing because philosophy's anthropomorphic orientation is ruptured by intuition; we are opened to a parallel relationship with nonhuman objects. On the other hand, it poses us a challenge on how to engage with durations that are inferior and superior to our own. ${ }^{33}$ Consequently, philosophy is re-defined as the quest for the nonhuman, and not anymore the search for the Absolute-the orthodox preoccupation of philosophical scholarship responsible for

\footnotetext{
${ }^{47}$ For Deleuze, duration and memory are identical in terms of principle and not in fact. In Bergsonism, he argues that the special problem of memory is: "How, by what mechanism, does duration become memory in fact? How does that which exists in principle actualize itself?" Ibid., 52.

${ }^{48}$ Ibid., 51; Cf. Bergson, "Introduction to Metaphysics," 193.

${ }^{49}$ Deleuze, Bergsonism, 52.

${ }^{50}$ Boundas, Translator's Introduction to Deleuze, Empiricism and Subjectivity, 5.

${ }^{51}$ Ibid.

52 This Bergsonian horizon has indisputably contributed to Deleuze and Guattari's conceptualization of the rhizome. They describe it as the non-arboreal connections and proximities existing between diverse and similar things, forces, and individuals. Cf. Deleuze and Guattari, A Thousand Plateaus, 21.

${ }^{53}$ Deleuze, Bergsonism, 28.

(c) 2016 Raniel SM. Reyes

http://www.kritike.org/journal/issue 19/reyes december2016.pdf

ISSN 1908-7330
}

(cc) BY-NC-ND 
actuating various predicaments in the history of western philosophy theoretical or otherwise.

However, it must be made clear that this so-called Bergsonian revolution is divergent from Kantian epistemology's privileging of concepts. Bergsonism does not aspire to vanquish the boundaries of the human in pursuit of the realm of concepts. ${ }^{54}$ Rather, it attempts to overcome everything that is pondered as human experience towards the conditions of experience or real experience in all its contingencies. The realm of the nonhuman, according to Moulard-Leonard, pertains to the realm of the unconscious. ${ }^{55} \mathrm{In}$ Anti-Oedipus: Capitalism and Schizophrenia, Deleuze and Guattari describe the realm of the non-human as an ontological and virtual state, and not simply psychological and actual: "For the unconscious itself is no more structural than personal, it does not symbolize any more than it imagines or represents; it engineers, it is machinic. Neither imaginary nor symbolic, it is the Real in itself, the 'impossible real' and its production." ${ }^{56}$ This characterizes the philosophy of virtual or transcendental empiricism. Its "virtuality" or "transcendentality" is shaped by its overarching project of seeking for the necessary conditions of the real (reality). For Deleuze, this radical initiative is informed by the significant quest for the various articulations that precondition these contingencies. Deleuze further argues that these conditions are not "Kant-like" or conditions of all possible experience in general derived from the real's immanent in commensurabilities which they attempt to mediate or mimic what they are supposed to condition and then projected back retrospectively. ${ }^{57}$ Instead, they are generic conditions of real experience, which are qualitatively diverse from the conditioned. According to Deleuze:

For when we have followed each of the 'lines' beyond the turn in experience, we must also rediscover the point at which they intersect again, where the directions cross and where the tendencies that differ in kind link together again to give rise to the thing as we know it .... After we have followed the lines of divergence ... these lines must intersect again, not at the point from which we started, but rather at a virtual point, at a virtual image of the

${ }^{54}$ In other words, it revolutionizes even the Copernican revolution of Kant. In Deleuze's observation, the radicalization of Kantian metaphysics opens the gate for the discursive expansion of the plane of immanence. See Moulard-Leonard, Deleuze-Bergson Encounters, 3.

${ }^{55}$ Cf. Ibid., 102

${ }^{56}$ Gilles Deleuze and Felix Guattari, Anti-Oedipus: Capitalism and Schizophrenia, trans. by Robert Hurley, Mark Seem, and Helen R. Lane (Minneapolis, MN: University of Minnesota Press, 1983), 53.

${ }^{57}$ Ibid., 100.

(c) 2016 Raniel SM. Reyes

http://www.kritike.org/journal/issue 19/reyes december2016.pdf

ISSN 1908-7330 
point of departure, which is itself located beyond the turn in experience. ${ }^{58}$

Bergson describes this virtual point or the virtual as the harmony existing between mind and matter, the privileging of duration over space, as well as the protean creativity of difference. ${ }^{59}$

The rupture of our anthropocentric and subjective durations is parallel to the kind of memory (recollection-memory) elusive to our present duration. In Matter and Memory, Bergson asserts that "We become conscious of an act sui generis by which we detach ourselves from the present in order to replace ourselves, first in the past in general, then in a certain region of the past-a work of adjustment ... But our recollection still remains virtual; we simply prepare ourselves to receive it by adopting the appropriate attitude." 60 Additionally, what must be made clear here is that in the planes of intuition, duration, and memory, the past and the present are viewed as coextensive moments, and not successive instances. One is the eternal past, by which all presents pass; and the other is the eternal present, or that which is always present. The "eternality" of the past or what Bergson and Deleuze call as pure past or past in general, does not follow the present, but is "presupposed by it as the pure condition without which it would not pass." 61 And because each instance of the present returns to itself as past, as Deleuze elucidates, "not only does the past coexist with the present that has been, but as it preserves itself in itself (while the present passes), it is the whole, integral past; it is all our past, which coexists with each present." 62 Hence, Bergson's notion of duration refers to virtual coexistence-the coexistence with itself of all the levels, all the tensions, all the degrees of contraction. ${ }^{63}$ Albeit I mentioned earlier that duration is constitutive of continuous succession (an overarching claim in Bergson's Time and Free Will), this claim is only true in so far as it is interpreted as virtual coexistence.

${ }^{58}$ Cf. Deleuze, Bergsonism, 28.

${ }^{59}$ Henri Bergson, Time and Freewill, trans. by F.L. Pogson (London: George Allen Unwin, Ltd., 1950; New York: Macmillan \& Co., 1919). The concept virtual first appears in this book. Cf. Deleuze, Begrsonism, 39.

${ }^{60}$ Bergson, Matter and Memory, 133-134.

${ }^{61}$ Deleuze, Bergsonism, 59; See also Friedrich Nietzsche, "On the Vision and the Riddle," in Thus Spoke Zarathustra: A Book for Everyone and No One, trans. by R.J. Hollingdale (London: Penguin Books, 1969), 155.

62 Deleuze, Bergsonism, 59.

${ }^{63} \mathrm{Ibid} ., 60$. To further explain the idea of coexistence, Deleuze, in Bergsonism, uses the metaphor of the cone. For Deleuze, the past ' $A B$ ' coexists with the present ' $S$ ' in the sense that it includes in itself all the sections $\left(\mathrm{A}^{\prime} \mathrm{B}^{\prime}, \mathrm{A}^{\prime \prime} \mathrm{B}^{\prime \prime}\right.$, etc.) which measure the degree of a purely ideal distance in relation to 'S.' All these sections are virtual that belongs to the totality of the past. See Ibid., 59-60.

(c) 2016 Raniel SM. Reyes

http://www.kritike.org/journal/issue 19/reyes december2016.pdf

ISSN 1908-7330

(c) ) BY-NC-ND 
Duration as virtual coexistence resembles Deleuze's characterization of the virtual. It is because the virtual subtends all beings like a rhizome as it undermines all a priori notions or segmented planes of representation. Given this aptitude, the virtual resides in variegated singularities and potentialities where the thought of pure immanence can be fashioned. Philosophical production of this kind necessitates an experimentation with our integral experience. Furthermore, the reality of the virtual is contrary to the Kantian and Husserlian understanding of experience. It goes beyond the quantitative variations and homogenous frames of scientific and metaphysical knowledge.

To probe deeper into the philosophical context of the virtual, it is significant to accentuate that for Bergson, an object can be separated into a thousand of ways. But before they are divided, the mind (thought) has already grasped them as conceptual possibilities. These objects, Deleuze expounds, already become perceivable in the object's image. And although they are not realized (only possible), they are actually perceivable in principle. ${ }^{64}$ This form of actuality (possible), the realm of matter, is what Bergson refers to as objectivity or the objective. And since objectivity only transforms quantitatively and remains immutable qualitatively during the division process, it is bereft of virtuality. This elucidation alludes to Deleuze's relative abhorrence to the Hegelian dialectics: "We are told that the Self is one (thesis) and it is multiple (antithesis), then it is the unity of the multiple (synthesis). Or else we are told that the One is already multiple, that being passes into nonbeing and produces becoming .... The concrete will never be attained by combining the inadequacy of one concept with the inadequacy of its opposite." 65 Therefore, the dialectical method is dismissed by Bergson as an inauthentic movement whereby the abstract concept travailing from one opposite to the other is only by virtue of inexactitude. Meanwhile, subjectivity or the subjective is pondered by Deleuze as qualitative multiplicity. In the process of division, it transforms in kind and traverses heterogeneous planes. Subjectivity, Deleuze writes, "moves from the virtual to its actualization, it actualizes itself by creating lines of differentiation that correspond to its differences in kind." 66 In other words, qualitative multiplicity surfaces the creative marriage between heterogeneity and continuity which engenders the virtual. ${ }^{67}$

It is likewise very important to contrast the virtual with the concept of the possible. The idea of the possible merely pertains to an uncovering of

\footnotetext{
${ }^{64}$ Cf. Ibid., 41.

${ }^{65} \mathrm{Ibid} ., 44$.

${ }^{66}$ Ibid., 43.

${ }^{67}$ Like Hume and other immanent philosophers, Bergson goes against the grain of the Hegelian dialectics by describing it as a false movement. Cf. Ibid., 44-47.
}

(C) 2016 Raniel SM. Reyes http://www.kritike.org/journal/issue 19/reyes december2016.pdf ISSN 1908-7330 
what already exists, i.e., it is already assured of what will happen in the future. ${ }^{68}$ Its occurrence is shaped through its conformity with the logic of identity where its entirety depends on a pre-formed element or eidos. The possible is the brother of the actual. Both of them are descendants of the multiplicity of space. Being mired by the logic of exteriority, homogeneity, and discontinuity, the possible is not hospitable to the existence of totally new or unthinkable events. Science and metaphysics can only bestow us the actual and the possible. Their incapability to surmount the quantitative differentiation existing between things, and their incapacity of qualitative self-differentiation alienates the possibility of philosophizing about the virtual. As Deleuze avers, whereas the possible "has no reality (although it may have an actuality); conversely, the virtual is not actual, but as such possesses a reality." 69 In Proust and Signs, he defines the virtual as the "real without being actual, ideal, without being abstract." 70 This means that the virtual is a state of existence actualized by virtue of undergoing differentiation, in the same vein that it is compelled to differentiate itself by formulating its own lines of differentiation as a necessary condition of its actualization.

It is only the multiplicity of duration that is hospitable to the virtual. Duration's ability of continuous and qualitative self-differentiation spawns the overcoming of the quantitative, the scientific, metaphysical, and the human, thereby opening to the horizon of the virtual. Although Deleuze perceives that the multiplicity of duration is the pure side, it does not necessarily convert duration into something beyond divisibility and measurement. In other words, instead of restricting himself with the antagonism between duration and space, or with the pedigree of the former over the latter, he reformulated this negative relation by formulating the two kinds of multiplicity. As Keith Ansell Pearson explains, Deleuze's critical appropriation of the virtual presents an ontological challenge to our traditional understanding of the one and the many, substance and subject, and more importantly, duration and space. ${ }^{71}$

Aside from Deleuze's thematic reconstruction of the Bergsonian philosophy of intuition, Deleuze radicalizes the concept of the virtual in order

${ }^{68}$ In Bergsonism, Deleuze contrasts the concept "discovering" with "inventing". The former refers to a process where one discovers what is already there or that which would certainly happen sooner or later. The latter, on the other hand, allows the existence of an event which escapes one's appropriation or to that which might never have happened. Cf. Deleuze, Bergsonism, 14.

${ }^{69} \mathrm{Ibid} ., 96$

${ }^{70}$ Gilles Deleuze, Proust and Sign, trans. by Richard Howard (Minneapolis: University of Minnesota Press, 2000), 58, 61.

${ }^{71}$ Cf. Keith Ansell Pearson, Philosophy and the Adventure of the Virtual: Bergson and the Time of Life (New York: Routledge, 2002), 4.

(c) 2016 Raniel SM. Reyes

http://www.kritike.org/journal/issue 19/reyes december2016.pdf

ISSN 1908-7330

(c) $\mathrm{BY}-\mathrm{NC}-\mathrm{ND}$ 
to expand its theoretical scope, especially in relation to contemporary scholarship and social criticism. He uses the philosophy of the virtual as the underlying theme of his philosophy of difference, non-philosophy, micropolitics etc., that profoundly backbones his overarching definition of philosophy as the creation of new concepts capable of radicalizing the grain towards a people, earth, and revolution-to-come.

\section{Conclusion: Multiple Durations and the Monism of Time}

While it seems that Bergson's distinct way of overcoming the predicament of transcendental philosophy is laden with binary opposites, like difference in degree and difference in kind, recollection-memory and contraction-memory, past and present etc., in the final analysis, he views all of these concepts within the yardsticks of virtual coexistence or concurrence (instead of dualism and succession). This is very evident, for example, in the last chapter of Bergsonism, "Elan Vital as Movement of Duration," where Deleuze raises the problem and concern on how these concepts can be harmonized. ${ }^{72}$ Although some may still dismiss it as a mere reformulated version of dualism, Deleuze explains that this "radical dualism" is selfcritical, protean, and non-teleological. Take the case of the relationship between the past and the present. Not only does the past coexist with the present. It also coexists differentially with itself on various planes of contraction. Meanwhile, the present itself must be identified as simply the most contracted plane of the past. ${ }^{73}$ This means that a profounder contractionmemory is discoverable within the core of recollection-memory. All in all, understanding all of these so-called binaries using the lens of virtual coexistence, would lead pure present and pure past, pure perception, pure memory, pure matter and pure memory, into a state of ontological unity. This state of differential coherence is termed by Deleuze as the difference in kind between things, or the differences of expansion and contraction. ${ }^{74}$

Speaking of Deleuze's rediscovered monism earlier, it seems that Bergson's philosophy has subtly succumbed to the logic of transcendental philosophy. However, in Deleuze's view, monism in this context should only

${ }^{72}$ Cf. Deleuze, Bergsonism, 91

${ }^{73}$ Cf. Ibid., 74.

${ }^{74}$ To further explain the concept of unity, Deleuze writes in Bergsonism, "What is a sensation? It is the operation of contracting trillions of vibrations onto a receptive surface. Quality emerges from this that is nothing other than contracted quantity. This is how the notion of contraction allows us to go beyond the duality of homogenous quantity and heterogeneous quality, and to pass from one to the other in a continuous movement. But, conversely, if our present, through which we place ourselves inside matter, is the most contracted degree of our past, matter itself will be like an infinitely dilated or relaxed past so relaxed that the preceding moment has disappeared when the following appears." Ibid. 
be understood along the premise that 'everything is duration.' What Deleuze infers at this juncture is that duration is dissolved in all the differences in degree between things, intensity, relaxation, and contraction that affect it, that thereby metamorphose into a kind of quantitative pluralism (from dualism to pluralism). ${ }^{75}$ But he interrogates whether this transformation entails a generalized pluralism or a limited one. Based on his examination, Bergson's Matter and Memory and Time and Free Will, he affirms the radical plurality of durations: "The universe is made up of modifications, disturbances, changes of tension and of energy, and nothing else."76 A more developed description of the possibility of manifold durations can be gleaned from Bergson's later book Creative Mind where he claims that our duration is only part of an infinity of durations. ${ }^{77}$

Furthermore, Deleuze utilizes Bergson's Matter and Memory, among others, as a catalyst in the characterization of his metaphysics, i.e., of Being as characterized by a plurality of durations, including our very own, caught at the middle of more dispersed and concentrated durations. This causes Deleuze to think that the virtual coexistence of all the planes of the past, of all the levels of tension, is extended to the entire universe. In his words, "This idea no longer signifies my relationship with being, but the relationship of all things with being. Everything happens as if the universe were a tremendous Memory." 78 And by virtue of intuition, idealism and realism are overcome, and more importantly, all things exterior, inferior, and superior to us, coexist without intricacy.

At this point, it appears that duration is characterized by a generalized or a multiplicity of durations. On the contrary, in Creative Evolution, Bergson underlines the idea that if things that endure, they are less in themselves or "absolutely than in relation to the Whole of the universe in which they participate." 79 In short, the answer to the previously raised query is that there is a limited pluralism encompassing reality (human and the nonhuman). I think it is more expedient to confront this problem constructively. It would be better to problematize the relationship of limited duration in generalized pluralism, than completely eradicating the possibility of an infinity of durations, i.e., generalized pluralism. When we consult Deleuze for a possible escape or lucidity from this quandary, he would nevertheless assert that the true problem that must be answered is not the problematization that I have previously stated, but the identification of the multiplicity of time. In order to possibly reconcile the seeming divergence

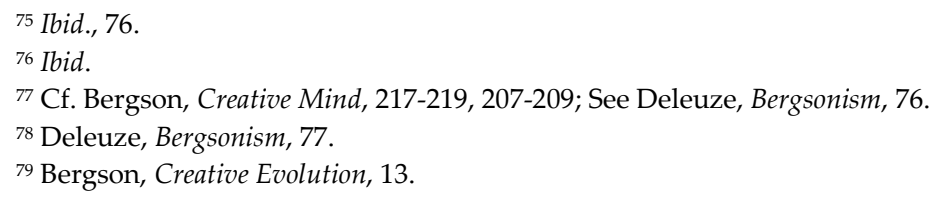


between my idea and Deleuze's, I would capitalize on his answer to the aforementioned question regarding the multiplicity of time. For him, the answer to this question must primarily address the discourse cultivated by its presupposition. Deleuze thinks that the multiplicity of time presupposes that Bergson believes in the monism of Time-single, universal, and impersonal Time. ${ }^{80}$ In this kind of universe, duration bears the capacity to apportion without dividing, to become simultaneously one and several, and to encompass itself (triplicity of durations). ${ }^{81}$ Our durations, Deleuze thinks, bear the deep-seated capability to reveal other durations, to integrate theirs, and encompass ourselves interminably.

With the creative power of duration, time becomes a virtual multiplicity constitutive of unremitting qualitative self-heterogeneity or virtual simultaneity of fluxes. The divided elements or fluxes that differ in kind and are crafted by duration can only be lived or efficiently rendered in the domain of a single Time. ${ }^{82}$ Put differently, whether the division spawned by duration leads to rendition (actual) or not (virtual), both can only be lived in a monism of Time. To reconcile the quandaries raised earlier, Deleuze explains:

There is only one time (monism), although there is an infinite of actual fluxes (generalized pluralism) that necessarily participate in the same virtual whole (limited pluralism). Bergson in no way gives up the idea of difference in kind between actual fluxes; any more than he gives up the idea of differences in relaxation or contraction in the virtuality that encompasses them and is actualized in them .... Not only virtual multiplicities imply a single time, but duration as virtual multiplicity is the single and same Time..$^{83}$

Affirming that there is a difference in kind existing between two tendencies or directions, like between duration and space, is insufficient for Deleuze. It is because one of the tendencies does not merely take all the

${ }^{80} \mathrm{Cf}$. Deleuze, Bergsonism, 80. The idea of a monism of Time remains a hypothesis for Bergson. But it is a hypothesis that can account for the nature of virtual multiplicities (duration). In Bergsonism, Deleuze explicates that in Duration and Simultaneity, Bergson formulates three hypotheses in relation to the kind of pluralism that can be attributed to duration, namely, generalized pluralism, limited pluralism, and monism. See Deleuze, Bergsonism, 78; See Henri Bergson, Duration and Simultaneity, trans. by Leon Jacobson (Indianapolis: Bobbs Merrill, 1965), 45-46.

${ }^{81}$ Cf. Deleuze, Bergsonism, 80.

82 Ibid.

${ }^{83}$ Ibid., 83. 
differences in kind on itself. Similarly, the differences in degree proceed to the other tendencies. In the case of duration, it involves all qualitative differences to others and to itself. In the case of space, on the other hand, all that vary quantitatively are involved. Therefore, there is "no longer any difference in kind between two tendencies, but a difference between the differences in kind that correspond to one tendency and the differences in degree that refer back to the other tendency." 84 This moment entails virtual concurrence. Between duration and matter are all degrees of difference or the whole nature of difference. ${ }^{85}$ Differences in degree are the lowest, while differences in kind, are the highest nature of Difference for Deleuze. Under the principle of Difference, all degrees exist concomitantly in a 'single Nature that is expressed in the one hand, in differences in kind, and on the other, in differences in degree.' 86 But it should be underscored that the coexistence of all the degrees of Difference is virtual in the same vein that the concept of differential unity bears a similar quality.

Ultimately, all the levels of contraction and expansion simultaneously exist in a monism of Time that thereby forms a Whole (pure virtuality). ${ }^{87}$ However, the 'Whole' is not a pre-determined or default reality. The Whole is always enmeshed in a creative movement of differentiation-of "virtuality in the process of being actualized, a simplicity in the process of differentiating, a totality in the process of dividing up." 88

$$
\begin{array}{r}
\text { Department of Philosophy } \\
\text { Research Center on Culture, Education and Social Issues } \\
\text { The Graduate School } \\
\text { University of Santo Tomas, Philippines }
\end{array}
$$

\section{References}

Ansell Pearson, Keith, Philosophy and the Adventure of the Virtual: Bergson and the Time of Life (New York: Routledge, 2002).

Bell, Jeffrey, "Between Individualism and Socialism: Deleuze's Micropolitics of Desire," in Jeffrey Bell's Selected Writings - Southern Louisiana University

Faculty Links (17 October 2003),

$<$ https://www2.southeastern.edu/Academics/Faculty/jbell/micropoliti cs.pdf $>$.

Cressole, Michel, Deleuze (Paris: Editions Universitares, 1973).

$$
\begin{aligned}
& { }^{84} \text { Ibid., } 93 . \\
& { }^{85} \text { Cf. Ibid., } 93 . \\
& { }^{86} \text { Ibid. } \\
& { }^{87} \text { Cf. Ibid. } \\
& { }^{88} \text { Ibid., } 94 .
\end{aligned}
$$


Bergson, Henri, Creative Mind, trans. by Mabelle Andison (New Jersey: Littlefield, Adams \& Co., 1965). Duration and Simultaneity, trans. by Leon Jacobson (Indianapolis: Bobbs Merrill, 1965). Matter and Memory, trans. by N. M. Paul and W. S. Palmer (New York: Zone Books, 2002). Time and Freewill, trans. by F.L. Pogson (London: George Allen Unwin, Ltd., 1950; New York: Macmillan \& Co., 1919).

Deleuze, Gilles, Bergsonism, trans. by Hugh Tomlinson and Barbara Habberjam (New York: Zone Books, 1988). Difference and Repetition, trans. by Paul Patton (New York: Columbia University Press, 1994). Empiricism and Subjectivity: An Essay on Hume's Theory of Human Nature, trans. by Constantin Boundas (New York: Columbia University Press, 1990). Essays Critical and Clinical, trans. by D.W. Smith and M. A. Greco (Minneapolis: University of Minnesota, 1997). Negotiations, trans. by Martin Joughin (New York: Columbia University Press, 1995). Nietzsche and Philosophy, trans. by Hugh Tomlinson (London: Athlone Press, 1983). "Nomad Thought," in The New Nietzsche, ed. by Donald Allison (Cambridge: MIT Press, 1985). Proust and Signs, trans. by Richard Howard (New York: George Braziller, 1972).

Deleuze, Gilles, and Felix Guattari, A Thousand Plateaus: Capitalism and Schizophrenia, trans. by Brian Massumi (Minneapolis: University of Minnesota Press, 1987). Anti-Oedipus: Capitalism and Schizophrenia, trans. by Robert Hurley, Mark Seem, and Helen R. Lane (Minneapolis, MN: University of Minnesota Press, 1983). What is Philosophy? trans. by Hugh Tomlinson and Graham Burchell (New York: Columbia University Press, 1994).

Deleuze, Gilles and Parnet, Claire, Dialogues, trans. by Hugh Tomlinson and Barbara Habberjam (London: Athlone Press, 1987).

Derrida, Jacques, Writing and Difference, trans. by Alan Bass (Chicago: University of Chicago Press, 1978).

Hegel, G.W.F., Science of Logic, trans. by A. V. Miller (London: Allen \& Unwin; New York: Humanities Press, 1969). The Hegel Reader, ed. by Stephen Houlgate (Malden, MA: Blackwell Publishing, 1998). 


\section{DELEUZE'S BERGSONISM}

Moulard-Leonard, Valentin, Bergson-Deleuze Encounters: Transcendental Experience and the Thought of the Virtual (New York: State University of New York Press, 2008).

Nietzsche, Friedrich, Thus Spoke Zarathustra: A Book for Everyone and No One, trans. by R.J. Hollingdale (London: Penguin Books, 1969).

Parr, Adrian, ed., The Deleuze Dictionary (Edinburgh: Edinburgh University Press, 2005).

Zourabichvili, François, Deleuze: A Philosophy of the Event (Edinburgh: Edinburgh University Press, 2012). 